TETIANA KLYNINA,

National aviation university (Kyiv, Ukraine)

e-mail: tklynina@gmail.com,ORCID 0000-0002-0334-9852

\title{
PLACE OF THE UNITED STATES SECRETARY OF STATES IN THE POWER SYSTEM AND FORMATION OF THE COUNTRY EXTERNAL COURSE ( $X X$ - at the beginning of $X X I$ century): HISTORICAL BACKGRAUND
}

The article deals with the position of the head of the US Department of State - Secretary of State in the US government system and his role in shaping the country's foreign policy. The author emphasizes the lack of basic research on this topic and the availability of only factual material on the activities of the Secretaries of State in various historical periods of American history. It is noted that the Secretary of State's position is not quite similar to that of the Minister of Foreign Affairs, since he serves in this country in two roles: as the President's foreign policy chief adviser and as the head of a vast diplomatic corps. The author points out that the role and status of the Secretary of State is not regulated at the constitutional level and provides a list of powers of the Secretary of State and notes their extension since the creation of such office in 1789 . The author points out that, before the Second World War, in most cases, in the tandem, the President-Secretary of State was the second to formulate the foreign policy of the country and to initiate its implementation, and was able to do justice to the president. Secretaries of State such as R. Lansing, B. Colby, and C. Hughes have enjoyed the trust of their presidents and have had a significant influence on the conduct of American foreign policy. During the presidency of F. Roosevelt and G. Truman, these individuals were themselves Secretaries of State, maximally moving the heads of the State Department to the background, giving them the opportunity to "bring order" not in the foreign policy arena, but in the State Department. It was not positive for the role of the Secretary of State and his Office the adoption of the 1947 Act establishing the National Security Council and the separation of a separate position - the President's national security adviser. From this very moment, the leaders of the National Security Council began to popularize the idea that foreign policy is not just one of the activities of the state, but directly a component of national security. Of course, this has led to increased NNG involvement in the country's foreign policy, which has often led to conflicts between the President's National Security Advisor and the Secretary of State, and the US President himself has not always supported the latter. It is noted that the Secretaries of State under Presidents J. Kennedy, L. Johnson, and R. Nixon, J. Bush Jr. played a rather indirect role in the country's foreign exchange. In contrast, Presidents D. Eisenhower, R. Reagan, B. Clinton and B. Obama respected and acted in tandem with their secretaries of state.

Keywords: US; Secretary of State; executive power; State Department; foreign policy.

\section{Introduction}

The United States Department of State is the supreme executive authority in the field of government foreign policy. The Secretary of State, respectively, is the Secretary of State, a political figure who has broad powers and at the same time holds a leading position in the administration of the President of the United States and the National Security Council. However, despite the concordance of the State Department as an analogue of any foreign policy department of most countries, it does have certain foreign ministries that are not characteristic of other foreign ministries, functions and competencies. The situation is similar with the appointment of the Secretary of State. For example, in the structure of the Ministry of Foreign Affairs of Ukraine there are positions of the Minister of Foreign Affairs and the position of the State Secretary of the Ministry of
Foreign Affairs. In accordance with its authority, the Minister of Foreign Affairs is responsible for the development, implementation and implementation of the Program of Activities of the Cabinet of Ministers of Ukraine in the area of conducting state policy in the sphere of foreign relations of Ukraine. In his turn, the State Secretary of the Ministry of Foreign Affairs is the head of the civil service of the ministry, he is accountable to and under the control of the minister and his main tasks include ensuring the activities of the ministry, stability and continuity in work, organization of ongoing work related to the exercise of the ministry's powers (Law of Ukraine "On Central executive authorities"). In the United States, the Secretary of State's position is not analogous to that of Ukraine, as he has two roles in that country: as the president's chief foreign policy advisor and as the head of a huge diplomatic corps. In fact, it is worth 
paying attention to the dual nature and complexity of the Secretary of State's status.

\section{Materials and Methods}

The study uses the following methods of system analysis and synthesis, deductive, problem-chronological and comparison methods. The problem-chronological method was used when considering the role of the Secretary of State in shaping the country's external course in chronological order. This helped preserve historical continuity, present a unified picture and consider qualitative changes in the issue of increasing or decreasing the role of the Secretary of State in public service. One of the main methods of scientific research was the comparative method, which allowed, through comparison and analysis, to identify common and different features in the policies of American presidents in relation to their secretaries of state. This helped to carry out a certain gradation and to trace the degree of influence of the Secretary of State on the implementation of the country's foreign policy. The principle of historicism is also used, which allows us to consider the phenomenon we are studying in its development.

Among the great scientific work concerning American foreign policy, it is difficult to distinguish precisely those works that focus on the secretariat of state as a political institution. Undoubtedly, scientists are subject to the analysis of the Secretaries of State, but only through the lens of their activities in tandem with the President of the United States. You will find almost no thorough work on the impact on foreign policy, for example, R. Lansing, E. Stettinius, J. Byrnes, etc. More research has been devoted to such secretaries of state as K. Hell, J. Marshall, F. Dulles, or G. Kissinger. However, such attention is caused not so much by their performance as Secretary of State, but by the odiousness of their personality or previous merit in another sphere of life in American society. General aspects of the Secretary of State as a position in the system of state power are devoted to the work of Don Philpott (2015), T. Estes and E. Lightner (1976). R. Walker's work is interesting in terms of factual material, and although it does not directly reveal the role and place of foreign policy decision-making, it nevertheless provides an analysis of the foreign policy steps taken by various Secretaries of State (Walker, 1965).

\section{Results and Discussion}

The difficulty in determining the status and position of Secretary of State in the United States system of government is that the US Constitution itself does not give a full understanding of the mechanism for ensuring foreign policy. This issue has, in fact, been left without the attention of the creators of the US Constitution, which has no specific sections on foreign power.

However, the Constitution of the USA says that the President is the federal government who has the greatest responsibility for the United States' relations with foreign countries; appoint ambassadors, envoys and consuls; accepts foreign ambassadors and other statesmen; maintains, with the Secretary of State, all official contacts with foreign governments; through the Department of State, is responsible for the safety of US citizens abroad and foreign nationals in the United States (The Constitution of the United States, URL...). According to the official position of Washington and the "Foggy Bottom" (jokingly referred to as the State Department because of its location), the State
Department is the president's advisor and has overall responsibility for shaping and implementing the country's foreign policy. There are many examples in the history of the United States, however, which testify and continue to testify to the dramatic opposite of the stated official course.

The Secretary of State is a senior official in the United States federal government, who heads the US Department of State, and therefore has more political weight than is usually the Secretary of State for Foreign Affairs. The Secretary of State is a senior member of the Cabinet of Ministers of the United States and ranks third in the country's hierarchy of executive power after the President and Vice President of the United States (Philpott, 2015: 19). Since 1947, a law has been in place in the United States of America establishing the order in which a president is replaced by the following officials in a specific order: Vice-President, Speaker of the House of Representatives, Interim Senate, Secretary of State, etc. That is, the Secretary of State is the fourth official to replace the presidential power. The history of the United States of America knows six cases where secretaries of state subsequently held the office of President of the United States (for example, Thomas Jefferson). The very nomination for the post of Secretary of State is proposed by the President and approved by the Senate, but the Secretary of State remains accountable to the President of the United States.

The assignment of powers of the Secretary of State dates back to the eighteenth century, and more specifically to 1789 , when the first, but not the final, act of Congress by which these powers were determined was passed. However, the very post of Secretary of State was introduced long before the enactment of the congress act, as early as 1781 , and in its functional constituent was significantly different from the present, since it included purely administrative functions. Although, of course, some of the typical obligations of the time are still relevant today - to maintain friendly relations with other countries, conclude cooperation agreements, protect American citizens abroad, and more (Estes, Lightner, 1976: 39).

By the middle of the twentieth century, foreign policy, except in a few cases, was formulated and usually implemented by the Secretary of State. For example, Robert Lansing was a wonderful secretary to President Woodrow Wilson, but at the same time W. Wilson, not R. Lansing, set the agenda for foreign affairs. Although, in itself, Lansing's influence on US foreign policy was also significant in his tenure as Secretary of State, which is related to the decisive role and influence of the future high official on high-profile international disputes. As Secretary of State, he faced significant foreign policy challenges related to the US position in World War I. At first, Lansing advocated a kindly neutrality in the European conflict, and later gave way to W. Wilson in his commitment to the United States in the war and accompanied W. Wilson at the 1919 Paris Peace Conference. R. Lansing is also credited with establishing the Diplomatic Security Service, which was to recruit the first Special Agents of the Department of State whose purpose was to monitor the activities of the Central Powers in the United States before and during World War I. (Biographies of the Secretaries of State: Robert Lansing (1864-1928), URL...). After R. Lansing during the presidency of W. Wilson, the State Department went hand-inhand: B. Colby held office for only a year, followed by Secretary of State Ch. Hughes, who held the post during $B$.'s reign. Wilson, then $-W$. Harding and K. Coolidge. During 
his four years in office, Mr. Hughes was as close as possible to leading the country's foreign policy, which was due to his lack of experience in these presidents and his credibility with Mr. Hughes. In particular, he raised the prestige of the United States in Latin America, chaired the Washington Navy Conference of 1921-1922, which signed the Treaty of Five States, establishing the ratio of naval power among the five largest naval powers in the world and signed with the Japanese several agreements to restrict the deployment of Japanese and American forces in the Pacific. As a Secretary of state, Hughes also worked to improve the morale and professionalism of the State Department, supporting the Foreign Service Act of 1924 (known as the Rogers Act), which eventually led to the creation of a professional highly qualified foreign service (Biographies of the Secretaries of State: Charles Evans Hughes (1862-1948), URL...).

With the outbreak of World War II, the United States has finally moved away from the politics of isolationism and embarked on the path of building itself as a world power. It is clear that under such conditions and ambitious plans, the US presidents could not let the formation of the foreign exchange of the country at random. Therefore, from the 1940s to the present, every White House head has become more involved in foreign affairs leadership. Franklin Roosevelt, John Kennedy and Richard Nixon played quite active roles in foreign policy; in this regard, the powers and regulations of the Secretary of State have been weakened. For example, during the presidency of F. Roosevelt, the role of the Secretary of State in shaping the foreign policy course came to naught. F. Roosevelt was himself both President and Secretary of State, conducting so-called "personal diplomacy" (Yunglyud, 1996: 75-85). That is why the Secretaries of State during his presidency (K. Hell, E. Stettinius) focused not on the external course of the country, but on the internal development of the State Department, forming what would be called "home American rear."

After the death of Roosevelt, the new head of the Oval Office was G. Truman, a hitherto unknown Senator from South Carolina and an inconspicuous Vice President at the time of Roosevelt. During his reign, it seemed that his Secretary of State, J. Byrnes, had every chance of returning the State Department to the wake of the fairways of the country's foreign exchange, as G. Truman had no proper experience and had a close enough, in his opinion, relationship with his Secretary of State (McCoy, 1982). In particular, J. Byrnes appeared to have a "tradition" of not informing the president about foreign policy actions, and thus, J. Byrnes made the president as much as possible from participating in the country's foreign policy course. True, not for long. Yesterday's inexperienced president led the same game with his Secretary of State and, at the end of 1945-1946, restricted the participation of J. Byrnes and the entire State Department in shaping US foreign policy. The temporary rematch of the Department of State and its head dates back to the reigns of J. Marshall and D. Acheson, Secretary of State G. Truman, who managed to transfer many foreign affairs issues to their own offices, albeit not for long. The post of Secretary of State, which had been leveled before, began to lose its essence with the adoption of the National Security Act in 1947, which eventually led to the emergence of the post of National Security Advisor (McCoy, 1982). In fact, the Act created the equivalent of a British military cabinet, but only as an advisory body in power, and the Secretary of State became only one voice among many in the National Security Council, and usually not the most influential. Since the adoption of the Act, the National Security Council has become one of the most important planning authorities for the security component of US foreign policy. It is true that gradually the National Security and Defense Council switched from a nonessential component directly to foreign policy itself. After that, the struggle to influence the formation of the country's foreign policy was no longer between the President and the Secretary of State, but between the National Security Advisor and the Secretary of State. It was from that time that, unless a secretary was held by an influential military, the authority to develop the country's external course was not / was clearly in the National Security Council. John Campbell also has a certain opinion in The Foreign Affairs Fudge Factory, which points to the "loss of the State Department's central role in policy-making related to the influence of the military establishment on American foreign policy" (Campbell, 1971: 35). Subsequently, the former Secretary of State and well-known American General J. Marshall, named after the famous Marshall Plan (the program for American aid to the post-World War II countries), stated that he did not participate in its development and that "great people and business "used his famous name to promote his program (Willian, 2010: 191-192).

To secure foreign control, Presidents J. Kennedy, L. Johnson, and R. Nixon included in the White House the post of National Security Advisor, who was often more influential than the Secretary of State. In particular, Kennedy, in his election campaign, made 54 promises of foreign policy. $\mathrm{He}$ said that when he became president, he personally, and only he, would make the most important foreign policy decisions. And it was this promise that was fulfilled in the first place and, it should be said, very original. Kennedy appointed Chester Bowles, Deputy Secretary of State, and Assistant Secretary of State, Manning Williams, before Dean Rax himself was named Secretary of State. And, even after he became Secretary of State, Rax was forced to silently agree to the President's further intervention in his prerogatives. Without consulting him, Kennedy appointed E. Stevenson US Representative to the UN, George Ball as Deputy Secretary of State and Averell Harriman as Special Agent (Ivanyan, 1975: 347). It was difficult to suggest a more explicit hint from the president as to who would actually govern the country's foreign policy. As for President R. Nixon, when he was preparing to resume diplomatic relations with the People's Republic of China (after a decade of non-recognition of the country), he assigned the job to his national security adviser, Henry Kissinger, who did not even inform Secretary of State William Rogers about the events before the official statement (Biographies of the Secretaries of State: Henry A. (Heinz Alfred) Kissinger (1923-), URL ...). Later, G. Kissinger replaced $U$. Rogers as Secretary of State, retaining his post of national security adviser, thereby limiting himself from the risk of encroachment on these powers by any new White House staffer. (Yilson, 1995: 353). H.. Kissinger himself stated that one of the goals of bringing together two of his most important foreign policy posts the Assistant President and Secretary of State - was to move the foreign policy development process from the White House to the State Department, thus making the process more accessible for the Congress (Chetverikov, 1974: 199). In 1972, Congress, in order to somehow 
strengthen its control over the activities of the Secretary of State and passed a law that obliged the Secretary of State to notify within sixty days the conclusion of all executive branch agreements.

Although there were presidents who counted with the secretaries of state. For example, D. Eisenhower relied entirely on his Secretary of State, J. F. Dulles. According to Soviet researcher E. Ivanian, "When he came to the White House, Eisenhower hastened to let Senator Taft know that he could come to him without notice and no matter what the busy president did. Except for the President's closest aides, this privilege was granted to only one member of the Cabinet, Secretary of State John Foster Dulles" (Ivanyan, 1975: 296). In fact, during the presidency of D. Eisenhower, the Secretary of State and his department were not accountable to the president, and in his turn there was no control on his part over the activities of the Secretary of State.

Secretary of State at the time of Carter - Cyrus Vance had a certain and sufficient influence on his president. Most likely, this was due to a certain lack of knowledge of the President on foreign policy issues. However, as he gained experience, Carter began to ignore his Secretary of State and his advice on political issues. In general, S. Vance himself was not a very prominent political figure, and his resignation, after a failed rescue mission by US Embassy personnel captured by Iranian militants, remained largely unnoticed (Biographies of the Secretaries of State: Cyrus Roberts Vance (1917-2002), URL...).

As for President R. Reagan, he usually supported his Secretary of State. For example, Secretary of State A. Hague's actions during his reign were aimed at making the Department of State the centerpiece of the US foreign policy mechanism and fully concentrating US foreign policy management. However, such moves by A. Hague have raised concerns among the president's immediate surroundings, who have seen the Secretary of State's actions threaten to diminish the White House's influence on foreign policy-making and to control the implementation of important foreign policy measures. In 1982, in order to neutralize the Secretary of State, U. Clark was appointed Assistant President for Homeland Security, formerly Deputy Secretary of State, and his new powers were expanded significantly (Lobanov, 1982: 122). And although A. Haig failed to become the "leader" of the foreign policy president in full, still some US researchers point to a certain strengthening of the State Department, and directly to the Secretary, in the foreign policy establishment during his tenure. In particular, it turned out that R. Reagan did not approve of the organizational structure of the National Security Council for a long time, and when he eventually did, the State Department played a major role in coordinating interagency activities in the formulation and practical implementation of American foreign policy. In addition, this interagency group was headed by the First Deputy Secretary of State, and the work of the group was provided by a secretariat, which consisted mainly of State Department staff. Within the interagency group, there were regional and functional groups headed by the respective Assistant Secretaries of State, and these groups were responsible for developing plans and programs of foreign policy activities within their competence (Kengor, 2000: 181).

Another of his Secretary of State, George Schultz, has always been supportive of R. Reagan, especially with the conflicts that he had with the National Security Advisor. The latter rarely made widely publicized trips abroad, and often avoided it. J. Schultz himself was widely respected in American political circles. Significant is that during the Reagan presidency, a compromise version of the reorganization of the National Security Council was adopted, which provided for the redistribution of national security policy responsibilities between the State Department, the Pentagon, and the Central Intelligence Agency ( $\mathrm{CIA}$ ) while maintaining the coordinating powers of the president. security (Lobanov, 1982: 122). President B. Clinton and his Secretary of state had a close working relationship in foreign policy, Madeleine Albright, the first woman, and B. Clinton, a third woman, with Clinton. As Clinton later noted in her memoirs, "if the White House treated the State Department impudently, it usually led to negative consequences. The newly elected president (B. Obama author's note) assured me that this time it would be the other way around" (Clinton, 2014: 23). Indeed, B. Clinton and B. Obama, as D. Eisenhower and R. Reagan at one time, trusted their secretaries of state and did not artificially diminish their influence on the formation and implementation of the country's foreign policy. As a quantitative confirmation, during her tenure as Secretary of State, Clinton visited 112 countries in the world, and M. Albright ranks second with an index in 96 countries visited.

In general, today the Secretary of State is not only the US Department of State, but also a member of the National Security Council, which is nevertheless one of the most influential and discusses important foreign policy issues. In general, the State Department and US ambassadors have been doing routine work since the Second World War, and major issues such as relations with the Soviet Union (and today's Russian Federation), China, and the Middle East have been dealt with by either the National Security Advisor or the Corps the Secretary of State as the President's personal emissary (Yilson, 1995: 354).

\section{Conclusion}

The secretaries of state played a very important role in shaping and implementing the foreign policy of the United States. In addition to the Secretary of State, significant involvement in the formulation and implementation of foreign policy is taken by the State Department adviser and the head of the Policy Planning Group, the Head of the Information and Research Office, and the Head of the Political Department of the State Department. For a long period of time, especially with the gradual emergence of the United States of America on the world stage, between the President, the Secretary of State, and since 1947, and the national security adviser, there has been an informal political struggle for the "palm of primacy" in shaping the country's foreign policy. Unfortunately, in many cases, this struggle was not a win for the Secretary of State, resulting in him, as the head of the foreign policy chief, either having to obey and follow in the shadow of the US President (or his national security adviser) or resign. In general, the role and importance of the Secretary of State in American society is significant. Today's Secretary of State, along with the Minister of Finance, the Secretary of Defense and the Attorney General, are usually considered the four most important cabinet members because of the importance of their departments. The Secretary of State holds a Level 1 position and receives a salary set for that level (approximately $\$ 220,000$ ). The Secretary of State's stated responsibilities are to supervise the United States foreign 
service, immigration policy and to administer the State Department. He should also advise the president (who has his own foreign policy vision) on foreign affairs such as the appointment of diplomats, ambassadors, their recall and dismissal. The Secretary of State may negotiate, interpret and terminate treaties concerning foreign policy. $\mathrm{He}$ can also participate in international conferences, organizations and agencies as a US representative. The Secretary of State announces foreign policy issues to the US, Congress, and US citizens. The secretaries of state also have internal responsibilities assigned to them since 1789. These include the protection and safekeeping of the United States of Great Britain, as well as the preparation of some presidential proclamations. In the process of extradition from justice to the United States or from the United States, the Secretary serves as a channel of communication between foreign governments, the federal government, and the states. In the course of development and numerous reorganizations, most of the internal functions of the Secretary of State and his Office have been delegated to other bodies. Under federal law, the resignation of a president or vice president is only valid if stated in writing in a document delivered to the Secretary of State's office. As the most senior member of the cabinet, the Secretary of State is the third largest executive of the United States federal government after the president and vice president and fourth in the line of replacement. In general, it can be stated that despite the seriousness, responsibility and sufficiently wide-ranging system of the foreign policy department, the prestige of this service goes beyond its importance. And while US diplomacy is essential in the world today, the Secretary of State does not exist as such: here is a position, a person who holds this position, but not in the format and not with the perspectives and functions in which it was created in 1789And so it can be said that with the rise of US influence in the international arena, the role of the Secretary of State is diminishing.

\section{REFERENCES}

Biographies of the Secretaries of State: Charles Evans Hughes (1862-1948). Retrieved from: https://history.state.gov/ departmenthistory/people/hughes-charles-evans.

Biographies of the Secretaries of State: Cyrus Roberts Vance (1917-2002). Retrieved from: https://history.state.gov/ departmenthistory/people/vance-cyrus-roberts.

Biographies of the Secretaries of State: Henry A. (Heinz Alfred) Kissinger (1923-). Retrieved from: https://history.state.gov/ departmenthistory/people/kissinger-henry-a.

Biographies of the Secretaries of State: Robert Lansing (18641928). Retrieved from: https://history.state.gov/departmenthistory/people/lansing-robert.

Campbell, J. F. (1971). The Foreign Affairs Fudge Factory. N.Y.: Basic Books, Inc. Publishers.

Chetverikov, S. B. (1974). Who and how does US policy. Moscow: International Relations (In Russian).

Clinton, H. R. (2014). Hard Choices: A Memoir. New-York: Simon \& Schuster

Estes, T., Lightner, E. (1976). The Department of States. N.Y.

Ivanyan, E. A. (1975). The White House: presidents and policy. Moscow: Political literature press. 347 p. (In Russian).

Kengor, P. (2000). The Vice President, Secretary of State, and Foreign Policy. Political Science Quarterly, 115(2), 175-199. DOI: https://doi.org/10.2307/2657899.
Lobanov, S. I. (1982). "Foggy bottom" today in USA. Economy, Politics, Ideology, 7, 117-123 (In Russian).

McCoy, D. R. (1982). The Presidency of Harry S. Truman. Lawrence: University Press of Kansas.

Philpott, Don (2015). Understanding the Department of State. Bernan Press.

The Constitution of the United States. Retrieved from: https:// constitutionus.com/.

Walker, R. (1965). The American Secretaries of State and their diplomacy. New York: Cooper Square Publishers.

Willian, S. (2010). White. Majesty and Mischief. N.Y.: Kessinger Publishing, LLC.

Yilson, D. (1995). American government. Moscow: Publishing group Progress. 512 p. (In Russian).

Yunglyud, V. (1996). The last Secretary of State of the Franklin Roosevelt era in USA. Economy, Politics, Ideology, 9, 75-85 (In Russian).

\section{LIST OF REFERENCES LINK}

Иванян Э. А. Белый дом: президенты и политика. Москва: Издательство политической литературы, 1975. 347 с.

Лобанов С. И. "Фогги боттом" сегодня. США: экономика, политика, идеология. 1982. № 7. С. 117-123.

Уилсон Дж. Американское правительство: (Пер. с англ.). Москва: Издательская группа "Прогресс", "Универс", 1995. $512 \mathrm{c}$.

Четвериков С. Б. Кто и как делает политику США. Москва: Международные отношения, 1974. 240 с.

Юнгблюд В. Последний госсекретарь эпохи Франклина Рузвельта. США: экономика, политика, идеология. 1996. № 9. C. $75-85$.

Biographies of the Secretaries of State: Charles Evans Hughes (1862-1948). URL: https://history.state.gov/departmenthistory/ people/hughes-charles-evans (Accessed 22.02.2020).

Biographies of the Secretaries of State: Cyrus Roberts Vance (1917-2002). URL: https://history.state.gov/departmenthistory/ people/vance-cyrus-roberts (Accessed 22.02.2020).

Biographies of the Secretaries of State: Henry A. (Heinz Alfred) Kissinger (1923-). URL: https://history.state.gov/departmenthistory/people/kissinger-henry-a (Accessed 22.02.2020).

Biographies of the Secretaries of State: Robert Lansing (18641928). URL: https://history.state.gov/departmenthistory/ people/lansing-robert (Accessed 22.02.2020)

Campbell J. F. The Foreign Affairs Fudge Factory. N.Y.: Basic Books, Inc. Publishers, 1971.

Clinton H. R. Hard Choices: A Memoir. New-York: Simon \& Schuster, 2014.

Estes T., Lightner E. The Department of States. N.Y., 1976.

Kengor P. The Vice President, Secretary of State, and Foreign Policy. Political Science Quarterly. 2000. 115(2), 175-199. DOI: https://doi.org/10.2307/2657899

McCoy D. R. The Presidency of Harry S. Truman. Lawrence: University Press of Kansas, 1982.

Philpott Don. Understanding the Department of State. Bernan Press, 2015.

The Constitution of the United States. URL: https://constitutionus.com/ (Accessed 02.02.2020).

Walker R. The American Secretaries of State and their diplomacy. New York: Cooper Square Publishers, 1965.

Willian S. White. Majesty and Mischief. N.Y.: Kessinger Publishing, LLC, 2010. 
Тетяна Клиніна,

Наиіональний авіаційний університет (м. Київ, Украӥна)

e-mail: tklynina@gmail.com, ORCID 0000-0002-0334-9852

\section{МІСЦЕ ДЕРЖАВНОГО СЕКРЕТАРЯ США В СИСТЕМІ ВЛАДИ ТА ФОРМУВАННІ ЗОВНІШНЬОГО КУРСУ КРӒ̈НИ (ХХ - ПОчатОК ХХІ століття): ІСТОРИЧНИЙ АСПЕКТ}

Стаття присвячена місцю очільника Державного департаменту США - Державного секретаря в системі державної влади США та його ролі у формуванні зовнішнього курсу країни. Автор наголошує на відсутності фундаментальних досліджень із зазначеної теми і наявності лише фактографічних матеріалів щодо діяльності Державних секретарів в різні історичні періоди американської історії. Зазначається, що посада Державного секретаря не зовсім є аналогічною до посади Міністра закордонних справ, оскільки в цій країні він виступає у двох ролях: як головний радник президента з питань зовнішньої політики і як керівник величезного дипломатичного корпусу. Автор вказує, що роль та статус Державного секретаря не врегульована на конституційному рівні; надається перелік повноважень Державного секретаря і відзначається їх розширення 3 моменту виникнення такої посади в 1789 році. Показано, що до початку Другої світової війни в більшості випадків в тандемі "Президент-Державний секретар" саме другий формулював зовнішньополітичний курс країни, був ініціатором його здійснення і був спроможний переконати в ньому Президента. Вивчаючи біографії та діяльність таких державних секретарів як Р. Лансінг, Б. Колбі, Ч. Г'юз, автор доходить висновку, що вони користувалися довірою своїх президентів і мали суттєвий вплив на здійснення американської зовнішньої політики. А за часів президентства Ф. Рузвельта та Г. Трумена зазначені особистості були самі собі Державними секретарями, максимально посунувши очільників Державного департаменту на другий план, давши їм можливість "наводити порядки" не на зовнішньополітичній арені, а в Державному департаменті. На думку автора, не стало позитивним для ролі Державного секретаря і його відомства прийняття Акту 1947 року про заснування Ради національної безпеки і виокремлення окремої посади - Радника Президента 3 національної безпеки. Саме з цього часу очільники РНБ почали популяризувати ідею, що зовнішня політика - це не просто один з видів діяльності держави, а безпосередньо складова національної безпеки. Звісно, це призвело до посилення втручання РНБ у здійснення зовнішнього курсу країни, що досить часто призводило до колізій між Радником Президента з національної безпеки й Державним секретарем, до того ж сам Президент США не завжди підтримував останнього. Зазначається, що Державні секретарі при президентах Дж. Кеннеді, Л. Джонсоні, Р. Ніксоні, Дж. Буші-молодшому грали досить опосередковану роль в проведенні зовнішнього курсу країни. Тоді як президенти Д. Ейзенхауер, Р. Рейган, Б. Клінтон та Б. Обама поважали своїх Державних секретарів та діяли у тандемі 3 ними.

Ключові слова: США; Державний секретар; виконавча влада; Державний департамент; зовнішньополітичний курс.

(C) Tetiana Klynina

Надійшла до редакції: 03.03.2020

Прийнята до друку: 23.03.2020 